\title{
UDC 621.391 \\ SELECTION AND RECOGNITION OF THE SPECIFIED RADIO SIGNALS IN THE SW BAND
}

\author{
Bezruk V.M., Ivanenko S.A. \\ "Information and Network Engineering" department, Kharkiv National University of Radio Electronics, \\ Ukraine
}

Background. Currently, the wireless radio technologies are an intensively developing branch of the telecommunications industry, due to their high popularity as a result of their convenience for civilian and specialized applications. Currently, the frequency resources are already quite overloaded, which leads to electromagnetic compatibility problems. This problem can be solved by efficient use of the frequency resource; for this purpose, monitoring of the radio frequency resource use by means of automated radio monitoring is carried out. Now a lot of radio-electronic means are operating at the moment and their number is rapidly increasing every day, which can lead to the fact that not only radio signals can be received, but also unknown signals, which in turn can lead to recognition errors. The paper studies the algorithms of selection and recognition of given radio signals, which take into account the class of unknown signals.

Objective. The aim of the paper is to research the quality indicators of the selection and recognition algorithms for given radio signals in the presence of unknown signals during radio monitoring in the SW band.

Methods. Investigation of algorithms for selection and recognition of specified radio signals in the presence of unknown signals by the simulation method on real signal samples.

Results. The values of quality indicators of selection and recognition of specified radio signals in the presence of unknown signals that are acceptable for the practice of radio monitoring are obtained.

The proposed recognition algorithms should improve the quality of radio monitoring results, and thereby improve the results of radio monitoring.

Conclusions. The proposed algorithms for the selection and recognition of specified radio signals in the presence of unknown signals will improve the quality of radio monitoring in the SW band.

Keywords: radio monitoring; frequency resource; algorithms for selection and recognition of specified radio signals; unknown radio signals.

\section{Introduction}

Currently, the wireless radio technologies are an intensively developing branch of the telecommunications industry, due to their high popularity as a result of their convenience for civilian and specialized applications. A lot of radio-electronic devices are operating at the moment, and their amount is rapidly increasing every day. Currently, the frequency resource is already quite overloaded, which leads to electromagnetic compatibility problems.

This problem can be solved by effectively using the frequency resource. In order to control the usage of the radio frequency resource, automated radio monitoring (ARM) is performed. Radio monitoring is a complex space-spectral-time processing task of radio emissions (RE) existing in a wide frequency range [1].

To simplify the solution, it is decomposed into a number of relatively independent processing tasks, in particular, detection of RE, existing within individual frequency channels, selection and recognition of specified RE types, unknown RE detection, RE type recognition and the $\mathrm{RE}$ modulation parameter estimation. These tasks can be reduced to processing the signals corresponding to them at the output of scanning radio receiving complexes. In case of signal detection, the tasks of recognition of specified known signals should be solved from the perspective of which class of users the detected signal corresponds to: the primary class (licensed) or secondary users. It is also possible that the detected signal doesn't belong to any of the known signal classes, which is a priori unknown, and information about it is missing in the database. It should be noted that in this problem statement of signal recognition with an automated RM wasn't solved [3-5].

The article presents the results of research on the problem of selection and recognition of specified signals in the presence of unknown signals using an example of real radio signals typical for radio monitoring in the SW band.

The decisive rule of selection and recognition of specified signals in the presence of unknown signal class.

Due to the effect of interference and many other uncontrollable factors, the observed signals in the frequency channels have random nature with a priori unknown statistical characteristics. A priori uncertainty is usually overcome by using training samples of given signals. However, with ARM, there are many unknown 
signals for processing. As a result, the observed signal may not belong to the specified classes and must be assigned to $(\mathrm{M}+1)$-th class of signals that is not specified in the statistical sense. And its training samples for several reasons cannot be obtained. This complicates the solution of signal recognition problems in ARM and determines the relevance of using special methods of signal recognition in conditions of high a priori uncertainty, which differ from the known methods [5].

In mathematical statistics, similar decision conditions were considered for the problems of testing a simple hypothesis against a complex alternative [6]. Similar problems are also known for classifying anomalous observations [7], detecting signals using Student's t-statistics [8], and also detecting signals using the not Bayesian optimality criterion that provides a correct detection of given probability while minimizing its own signal area $[9,10]$. For signal recognition problems are offered approaches that in some cases allow building decisive recognition rules without using training samples of the $(\mathrm{M}+1)$-th signal $[11,12]$ or algorithms that are insensitive to the statistical characteristics of signals and interference which don't require knowledge of training samples of signals for their construction [13].

Let us consider the formalized formulation of this non-traditional formulation of the signal recognition problem. It is supposed that observations of signals in the analyzed frequency channels are represented by a L dimensional vector of discrete samples $\vec{X}$. The following $(\mathrm{M}+1)$-th hypotheses are set that can be made regarding to the observed signals: $H^{i}, i=\overline{1, M}$ for given signals, $\mathrm{H}^{0}$ - for unknown signals combined into the $(M+1)$-th class.

Suppose that training samples of $\mathrm{M}$ signals $\{i=\overline{1, M}\}$, are defined, and the training sample for the $(\mathrm{M}+1)$-th signal $(\mathrm{i}=0)$ is absent or unrepresentative. Such initial data for signal recognition can be characterized by the term "increased a priori uncertainty" and define the non-traditional task of selection and recognition of given signals in the presence of unknown signals $[10,11]$. The density probabilities of the given signals $\mathrm{W}\left(\overrightarrow{\mathrm{x}} \mid \vec{\alpha}^{\mathrm{i}}\right), \mathrm{i}=\overline{1, \mathrm{M}}$ are given to within random vector parameters $\vec{\alpha}^{i}$, $\mathrm{i}=\overline{1, \mathrm{M}}$, and for the $(\mathrm{M}+1)$-th class the density probability is unknown. A priori probabilities of the hypotheses $\mathrm{P}\left(\mathrm{H}^{\mathrm{i}}\right)=\mathrm{P}_{\mathrm{i}}$, are also given, where
$\sum_{i=0}^{M} P_{i}=1$. It is also assumed that training samples of signal realizations $\mathrm{M}$ are given $\left\{\overrightarrow{\mathrm{x}}_{\mathrm{r}}^{\mathrm{i}}, \mathrm{r}=\overline{1, \mathrm{n}_{\mathrm{i}}} ; \mathrm{i}=\overline{1, M}\right\}$, and there is no training sample for the $(M+1)$-th class of unknown signals $(i=0)$.

As part of the formulated non-classical signal recognition task, the signal recognition quality indicator is characterized by an average risk, which is determined by the following formula:

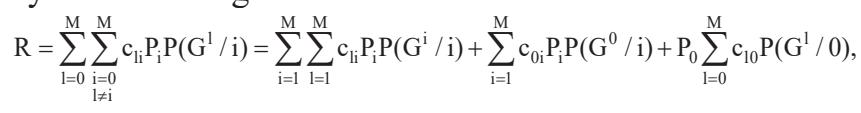

where $c_{l i}$ is the loss function; $P\left(G^{1} / \mathrm{i}\right)$ - the error probability in the case of making a decision in favor of the 1-th signal under the action of the i-th signal.

A non-randomized decision rule for recognition splits the sample signal space into the $(\mathrm{M}+1)$-th nonintersecting region. With this in mind, in formula (1), the first term is a component of the average risk due to the mixing up $M$ specified signals, the second term is due to assigning the given signals to the $(\mathrm{M}+1)$-th class of unknown signals, the third term is due to assigning signals from the $(\mathrm{M}+1)$-th class to $\mathrm{M}$ given signals.

For the formulated non-classical task of selection and recognition of specified signals in the presence of unknown signals, the following decision rule can be used [14]:

under the conditions:

$$
\begin{gathered}
\mathrm{H}^{\mathrm{i}}: \mathrm{P}_{\mathrm{i}} \mathrm{W}\left(\overrightarrow{\mathrm{x}} / \vec{\alpha}^{\mathrm{i}}\right) \geq \lambda^{\mathrm{i}}, \mathrm{i}=\overline{1, \mathrm{M}} \\
\mathrm{P}_{\mathrm{i}} \mathrm{W}\left(\overrightarrow{\mathrm{x}} / \vec{\alpha}^{\mathrm{i}}\right) \geq \mathrm{P}_{1} \mathrm{~W}\left(\overrightarrow{\mathrm{x}} / \vec{\alpha}^{1}\right), \quad 1=\overline{1, \mathrm{M}}, \quad 1 \neq \mathrm{i},
\end{gathered}
$$

the hypothesis $\mathrm{H}^{\mathrm{i}}$ is accepted about the action of the $i$-th specified signal.

if inequality is fulfilled

$$
\mathrm{H}^{0}: \mathrm{P}_{\mathrm{i}} \mathrm{W}\left(\overrightarrow{\mathrm{x}} / \vec{\alpha}^{\mathrm{i}}\right)<\lambda^{\mathrm{i}}, \mathrm{i}=\overline{1, \mathrm{M}},
$$

then the hypothesis $\mathrm{H}^{0}$ is accepted about the action of unknown signals;

Here, the threshold value $\lambda$ is determined from the condition of ensuring a given probability of correct recognition of given signals.

According to this rule, the decision in favor of the specified signal is taken in two stages: when at least one of the inequalities (2a) is fulfilled, and also when the system of inequalities is fulfilled (2b). When 
inequalities (2c) are fulfilled, the decision is made in favor of unknown signals from the $(\mathrm{M}+1)$-th class.

The decision rule (2) doesn't use information about the density distribution of the $(\mathrm{M}+1)$-th class of signals and doesn't require its training set. The formulation and solution of the considered recognition task is the formalization of a substantive requirement about the necessity to isolate (select) and recognize $\mathrm{M}$ specified signals and assign unknown signals to the $(\mathrm{M}+1)$-th class, information about which is missing.

Let's consider the case when a probability model in the form of orthogonal expansions is used to describe real signals in a frequency channel. In this case, the vector $\vec{X}$ is represented as a vector of spectral samples in a certain basis $\overrightarrow{\mathrm{C}}=\mathrm{X}^{\mathrm{tr}} \mathrm{B}$. In particular, the representation of signals as samples of the amplitude spectrum in the basis of discrete exponential functions (DEF) will be considered. Assuming the Gaussian distribution and the uncorrelated coordinates of the spectral samples vector, the correlation matrices of the spectral description become diagonal and decision rule (2) is simplified, and takes the following form [15]:

$$
\begin{aligned}
& H^{1}: \sum_{j=1}^{N} \frac{\left(c_{j}-\mu{ }_{j c}^{i}\right)^{2}}{\left(\sigma_{j c}^{i}\right)^{2}} \leq \Delta{ }_{c}^{i} ; i=\overline{1, M} \\
& \sum_{j=1}^{N} \frac{\left(c_{j}-\mu_{j c}^{1}\right)^{2}}{\left(\sigma_{j c}^{1}\right)^{2}} \leq \sum_{j=1}^{N} \frac{\left(c_{j}-\mu_{j c}^{k}\right)^{2}}{\left(\sigma_{j c}^{k}\right)^{2}}, 1=\overline{1, M} \\
& H^{0}: \sum_{j=1}^{N} \frac{\left(c_{j}-\mu_{j c}^{i}\right)^{2}}{\left(\sigma_{j c}^{i}\right)^{2}}>\Delta_{c}^{i}, i=\overline{1, M}
\end{aligned}
$$

where $c_{j}$ - expansions coefficients for observation vector $\vec{X}$ in DEF basis, $\mu_{j}^{0}, \quad\left(\sigma_{j}^{0}\right)^{2}$ - evaluation of the mathematical expectation and variances coefficients of expansion $c_{j}$, which are estimated by training samples of given signals; $\mathrm{N}$ - the dimension for the spectral representation of signals; $\Delta_{c^{-}}^{0}$ some threshold values selected from the condition of ensuring a given probability for correct recognition of specified signals.

Note that in the decision rule (3) information about unknown signals is not used and, consequently, their training samples are not required. Sometimes these rules can also be used to solve opposite task in practice - the detection of new (unknown) signals.

\section{The experimental research results of the selection and recognition task of specified signals}

The recognition research of specified signals in the presence of a class of unknown signals was performed by statistical tests on samples of real radio signals typical for radio monitoring in the SW band. During the experiment, samples of implementations of 9 real radio signals were obtained, corresponding to the RE in the frequency range regulated for the IEEE 802.22 standard. The samples records of signal realizations were obtained using a SDR receiver [15]. For these purposes, a USB DVB-T tuner was used, which can register signals for RE in the IEEE 802.22 standard operating range with the help of special software. As the program part of the SDR complex, the program SDR \# was used. The discrete sample records of radio signals in the frequency band of 12 $\mathrm{kHz}$ were obtained. Training and control samples for 70 realizations of each signal are aggregated. In research, the decision rule (3) was used, which was programmatically implemented in the MATLAB environment.

Fig. 1 illustrates the averaged amplitude spectra of the radio signals that were used as predetermined known signals. The signal spectra were obtained using the discrete Fourier transform (DFT) of signal realizations with duration for 128 discrete samples.

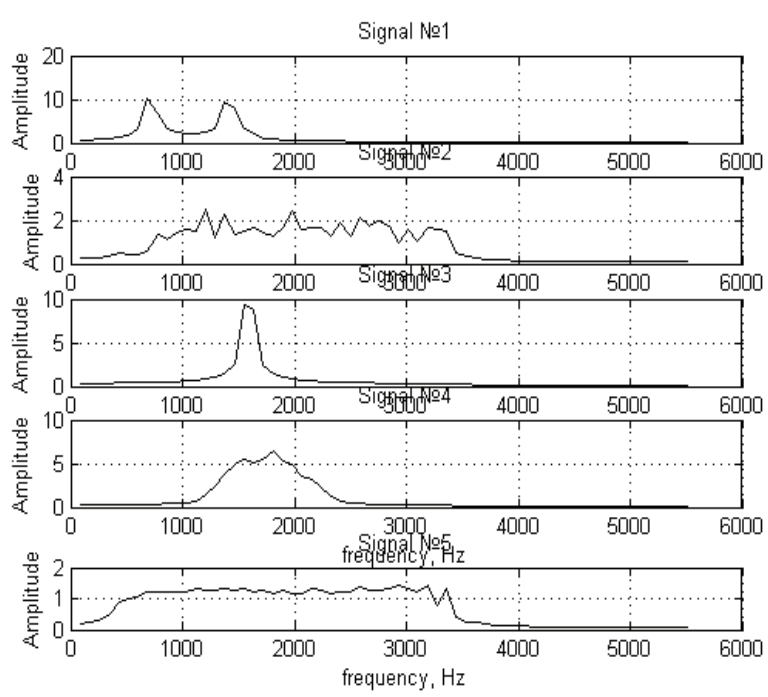

Fig. 1. Averaged amplitude spectra of given radio signals

Fig. 2 shows the averaged amplitude spectra of radio signals that were used as unknowns. 

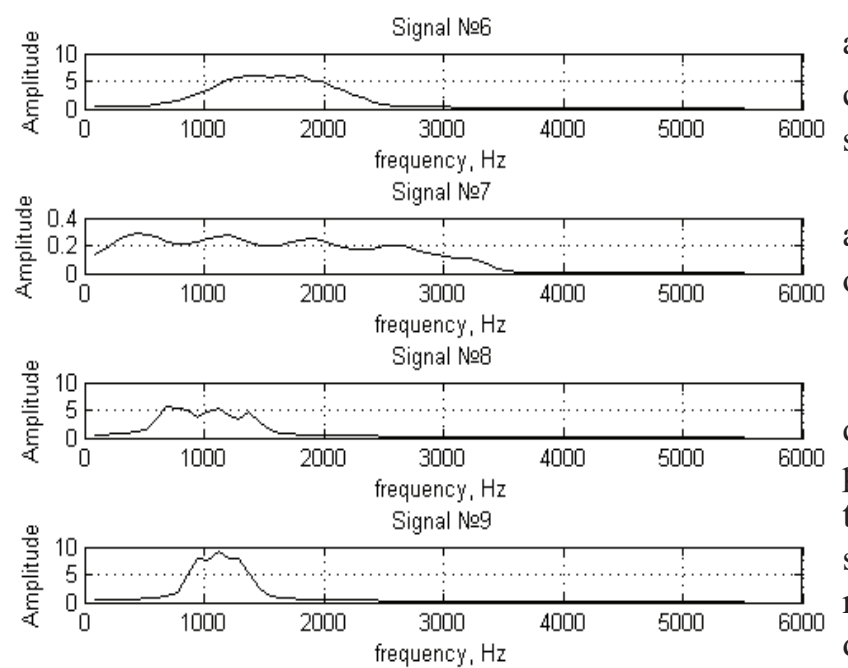

Fig. 2. Averaged amplitude spectra of unknown radio signals

The investigations of the probability properties of obtained real radio signals realizations made it clear that the selected spectral representation of the signals is subordinate to the Rice distribution, which under certain conditions turns into the Gaussian distribution. In addition, the calculated estimates of the correlation spectral representation function of real signals indicate practically the absence of correlated samples of the amplitude spectra of signals. This gives grounds to use decisive rules for recognizing signals in the form (3).

Accumulated training samples of realizations of the specified known radio signals were used to estimate the parameters of the decision rule (3). The threshold values $\Delta_{\mathrm{c}}$ were chosen from the condition for ensuring the specified probabilities of correct recognition of the specified radio signals. In the working mode, control realization samples of specified known and unknown radio signals were presented. By statistical tests, estimates were obtained for the probability of correct and wrong recognition of given and unknown radio signals as the ratio number of correctly or mistakenly assigned realizations to the total number of presented realizations for the corresponding signals.

Signals №1-5 were used as specified radio signals, the remaining four signals represented the first $(\mathrm{M}+1)$-th class of unknown radio signals. According to the results of statistical tests, the following recognition quality indicators were evaluated:
- the probability of wrong decisions about the action of unknown radio signals from the $(\mathrm{M}+1)$-th class, in case of presentation the specified radio signals $\mathrm{P}((\mathrm{M}+1) / \mathrm{i}), \mathrm{i}=1, \mathrm{M}$;

- the probability of wrong decisions about the action of given radio signals, in case of presentation of the unknown radio signals from $(\mathrm{M}+1)$-th class $\mathrm{P}(\mathrm{i} /(\mathrm{M}+1)), \mathrm{i}=1, \mathrm{M}$. ;

The obtained estimates of the recognition quality of radio signals using the decision rule (3) are presented in Table. 1 . Here are the recognition results of the specified and unknown radio signals with different signals observation duration, on which the signal realizations spectra were calculated (the DFT block dimension).

Table 1 . The results of real signals recognition

\begin{tabular}{|c|c|c|c|c|c|c|c|c|c|}
\hline \multirow{9}{*}{\begin{tabular}{c} 
Signal \\
$\begin{array}{c}\text { Secognition } \\
\text { probability }\end{array}$ \\
\cline { 2 - 11 }
\end{tabular}} & \multicolumn{10}{|c|}{128} \\
\cline { 2 - 11 } & 1 & 2 & 3 & 4 & 5 & 6 & 7 & 8 & 9 \\
\hline $\begin{array}{c}\text { DFT block } \\
\text { dimension, } n\end{array}$ & \multicolumn{10}{|c|}{$(j)$} \\
\hline $\mathrm{P}(1 / \mathrm{j})$ & 0.9 & 0 & 0.1 & 0 & 0 & 0 & 0 & 0 & 0 \\
\hline $\mathrm{P}(2 / \mathrm{j})$ & 0 & 0.9 & 0 & 0 & 0 & 0 & 0 & 0 & 0 \\
\hline $\mathrm{P}(3 / \mathrm{j})$ & 0 & 0 & 0.8 & 0 & 0 & 0 & 0 & 0 & 0 \\
\hline $\mathrm{P}(4 / \mathrm{j})$ & 0 & 0 & 0 & 0.9 & 0 & 0 & 0 & 0 & 0 \\
\hline $\mathrm{P}(5 / \mathrm{j})$ & 0 & 0 & 0 & 0 & 0.9 & 0 & 0 & 0 & 0 \\
\hline $\mathrm{P}(\mathrm{j} / \mathrm{M}+1)$ & 0 & 0.1 & 0 & 0 & 0.1 & 1 & 0 & 0.2 & 0.2 \\
\hline
\end{tabular}

Based on the results of table 1 the generalized values of the components of the wrong probability decisions are obtained, when solving the problem of recognizing specified radio signals in the presence of unknown radio signals according to the formula (1). In particular, the averaged probabilities of wrong decisions for the DFT block dimension 256 are given:

- on the action of unknown radio signals from the $(\mathrm{M}+1)$-th class, in case of presentation of the specified radio signals $\mathrm{P}((\mathrm{M}+1) / \mathrm{i})=\sum_{\mathrm{i}=1}^{\mathrm{M}} \frac{\mathrm{P}(0 / \mathrm{i})}{\mathrm{M}}=0.04$; - on the action of given radio signals, in case of presentation of the unknown radio signals in the 
amount of $\mathrm{T}$ from the $(\mathrm{M}+1)$-th class of unknown radio signals $\mathrm{P}(\mathrm{i} /(\mathrm{M}+1))=\sum_{\mathrm{i}=1}^{\mathrm{M}} \sum_{\mathrm{l}=1}^{\mathrm{T}} \frac{\mathrm{P}(\mathrm{i} / \mathrm{l})}{\mathrm{T} * \mathrm{M}}=0$;

- on mixing up the set radio signals among themselves $\mathrm{P}(\mathrm{i} /(\mathrm{M}))=\sum_{\mathrm{i}=1}^{\mathrm{M}} \sum_{\mathrm{j}=1}^{\mathrm{M}} \frac{\mathrm{P}(\mathrm{i} / \mathrm{j})}{\mathrm{M}^{2}}=0.004$.

The obtained research results on real-life radio signals samples confirm the possibility of using the proposed decision rule for solving the task of selection and recognition of the specified radio signals in the presence of a class of unknown radio signals when conducting automated radio monitoring in the SW band.

\section{Conclusions}

1. The paper considers a non-classical approach for solving the signal recognition task, which occurs during automated radio monitoring, i.e. when not only known radio signals, but also unknown radio signals are received for processing. It is proposed to use the decision rule for selection and recognition of specified signals in the presence of unknown signals, which is based on the signal description, operating in the frequency channel, by a probability model in the form of orthogonal expansions.

2. The results are presented about experimental research on the task of selection and recognition specified radio signals in the presence of unknown radio signals. The research have been performed with statistical tests on samples of real radio signals, typical for processing tasks with automated radio monitoring in the SW band.

3. The results of real radio signals recognition that are acceptable for practice have been obtained, which gives reason to recommend using the proposed decisive rule for recognizing specified known signals in the presence of unknown signals in the process of automated monitoring in the SW band.

\section{References}

1. Kokhanovich G.F., Babak V.P., Fisenko V.M. Special radio monitoring. - Kiev: MK-Press, 2007. $324 \mathrm{p}$.

2. Rembovsky, AM, Ashihmin AV, Kozmin VA .. Radiomonitoring: objectives, methods, tools. - M.: Hotline-Telecom, 2012. - $641 \mathrm{p}$.

3. Kim K. Cyclostationary approaches to signal detection and classification in cognitive radio / $/ \mathrm{New}$ frontiers in dynamic spectrum access networks. 2nd IEEE international symposium. - IEEE, 2007. - C. 212-215.
4. Duda R.O., Hart P.E., Stork D.G. Pattern classification 2nd Edition. - Wiley-Interscienceю, 2001. $-738 \mathrm{P}$.

5. Weber, C. Automatic modulation classification technique for radio monitoring/ C. Weber, M. Peter, T. Felhauer // Electronics Letters. - 2015. - Vol. 51, № 10. - P. 794-796.

6. Anderson T. Statistical analysis of time series. M .: Mir, 1976. - $755 \mathrm{p}$.

7. Ayvazyan S.A., Bezhaeva Z.I., Staroverov O.L. Classification of multidimensional observations. - M : Statistics, 1974. - 239 p.

8. Theory of signal detection / Ed. P.A. Bakuta. M .: Radio and communication, 1984. $-440 \mathrm{p}$.

9. Senin A.G. Recognition of random signals. Novosibirsk: Science, 1974. - 76 p.

10. Libenson M.N. Nonlinear statistical method for recognizing many classes // Problems of random search. - Riga: IC of the Academy of Sciences of Latvia, 1978. - Vol. 6. - P.299-317.

11. Omelchenko V.A. Basics of the spectral theory of signal recognition. - Kharkov: High school, 1983. $156 \mathrm{p}$.

12. Omelchenko V.A. Recognition of random signals in conditions of a priori uncertainty. - Kharkov: KhPI, 1979. $-100 \mathrm{p}$.

13. Fefelov N.A. Pattern recognition in the presence of a new class // Selection and processing of information. - 1988. - Vol. 2. - P.84-89.

14. Bezruk V.M., Pevtsov G.V. Theoretical foundations of the design of signal recognition systems for automated monitoring. - Kharkov: Collegium, 2007. - 430 p.Jondral F. K. Software-defined radio: basics and evolution to cognitive radio //EURASIP journal on wireless communications and networking. -2005 . $-\mathrm{T}$. 2005, №. 3. - P. 275-283. 


\section{Безрук В.М., Іваненко С.A.}

Селекція та розпізнавання заданих радіосигналів у КХ діапазоні

Проблематика. В даний час бездротові радіотехнології - галузь, що інтенсивно розвивається. Це обумовлено їх високою популярністю внаслідок зручності їх використання для цивільного та спеціалізованого застосування. В даний час частотний ресурс вже досить перевантажений, що призводить до проблем електромагнітної сумісності. Вирішити цю проблему можливо шляхом ефективного використання частотного ресурсу, для цих цілей проводиться контроль за використанням радіочастотного ресурсу шляхом автоматизованого радіомоніторингу. Зараз в ефірі працює безліч радіоелектронних засобів, і їх кількість стрімко зростає з кожним днем, що може призвести до того, що на обробку можуть потрапити не тільки відомі сигнали, але і невідомі, що в свою чергу може призвести до помилок розпізнавання. У даній роботі досліджуються алгоритми селекції та розпізнавання заданних радіосигналів, що враховують клас невідомих сигналів.

Мета досліджень. Метою роботи є дослідження показників якості алгоритмів селекції заданих радіосигналів при наявності невідомих сигналів під час радіомоніторингу в КХ діапазоні.

Методика реалізації. Дослідження алгоритмів селекції заданих радіосигналів при наявності невідомих сигналів проведено методом імітаційного моделювання на вибірках реальних сигналів.

Результати досліджень. Отримані значення показників якості алгоритмів селекції заданих радіосигналів, які $\epsilon$ придатними для практики радіомоніторінгу.

Висновки. Запропоновані алгоритми селекції та розпізнавання заданних радіосигналів дозволять підвищити якість результатів радіомоніторингу в КХ діапазоні.

Ключові слова: радіомоніторинг; частотний ресурс; алгоритми селекції і розпізнавання заданих радіосигналів; невідомі сигнали.

Безрук В.М., Иваненко С.А.

Селекция и распознавание заданных радиосигналов в КВ диапазоне

Проблематика. В настоящее время беспроводные радиотехнологии являются интенсивно развивающейся отраслью телекоммуникационной индустрии, что обуславливается их высокой популярностью вследствие удобства их использования для гражданского и специализированного применения. В настоящее время частотный ресурс уже достаточно перегружен, что приводит к проблемам электромагнитной совместимости. Решить эту проблему возможно путем эффективного использования частотного ресурса, для этих целей производится контроль за использованием радиочастотного ресурса путем автоматизированного радиомониторинга. Сейчас в эфире работает множество радиоэлектронных средств и их количество стремительно возрастает с каждым днём, что может привести к тому, что на обработку могут попасть не только известны радиосигналы, но и неизвестные сигналы, что в свою очередь может привести к ошибкам распознавания. В данной работе исследуются алгоритмы селекции и распознавания заданных радиосигналов, которые учитывают класс неизвестных сигналов.

Цель исследований. Целью работы является исследование показазателей качества алгоритмов селекции и распознавания заданных радиосигналов при наличии неизвестных сигналов во время радиомониторинга в КВ диапазоне.

Методика реализации. Исследование алгоритмов селекции и распознавания заданных радиосигналов при наличии неизвестных сигналов методом имитационного моделирования на выборках реальных сигналов.

Результаты исследований. Получены значения показателей качества селекции и распознавания заданных радиосигналов при наличии неизвестных сигналов, которые есть приемлемыми для практики радиомониторинга.

Предложенные алгоритмы распознавания должны повысить качество результатов радиомониторинга, и тем самым улучшить результаты проведения радимониторинга.

Выводы. Предложеннные алгоритмы селекции и распознавания заданных радиосигналов при наличии неизвестных сигналов позволят повысить качество радиомониторинга в КВ диапазоне.

Ключевые слова: радиомониторинг; частотный ресурс; алгоритмы селекции и распознавания заданных радиосигналов; неизвестные радиосигналы. 